\title{
Effect of short term diet restriction on gene expression in the bovine hypothalamus using next generation RNA sequencing technology
}

Daragh Matthews ${ }^{1,2}$, Michael G. Diskin ${ }^{1}$, David A. Kenny ${ }^{3}$, Christopher J. Creevey ${ }^{3}$, Kate Keogh ${ }^{3}$ and Sinead M. Waters ${ }^{3^{*}}$

\begin{abstract}
Background: Negative energy balance (NEB) is an imbalance between energy intake and energy requirements for lactation and body maintenance affecting high-yielding dairy cows and is of considerable economic importance due to its negative impact on fertility and health in dairy herds. It is anticipated that the cow hypothalamus experiences extensive biochemical changes during the early post partum period in an effort to re-establish metabolic homeostasis. However, there is variation in the tolerance to NEB between individual cows. In order to understand the genomic regulation of ovulation in hypothalamic tissue during NEB, mRNA transcriptional patterns between tolerant and sensitive animals were examined. A short term dietary restriction heifer model was developed which induced abrupt onset of anoestrus in some animals (Restricted Anovulatory; RA) while others maintained oestrous cyclicity (Restricted Ovulatory; RO). A third control group (C) received a higher level of normal feeding.

Results: A total of 15,295 genes were expressed in hypothalamic tissue. Between RA and C groups 137 genes were differentially expressed, whereas between RO and C, 32 genes were differentially expressed. Differentially expressed genes were involved in the immune response and cellular motility in RA and RO groups, respectively, compared to $\mathrm{C}$ group. The largest difference between groups was observed in the comparison between RA and RO heifers, with 1094 genes shown to be significantly differentially expressed (SDE). Pathway analysis showed that these SDE genes were associated with 6 canonical pathways $(P<0.01)$, of which neuroactive ligand-receptor interaction was the most significant. Within the comparisons the main over-represented pathway functions were immune response including neuroprotection (CXCL10, Q1KLR3, IFIH1, ILI and IL8; RA $\vee C$ and RA $\vee$ RO); energy homeostasis (AgRP and NPY; RA $\vee$ RO); cell motility (CADH1, DSP and TSP4; RO $\vee C$ ) and prevention of GnRH release (NTSR1 ILIa, ILI $\beta$, NPY and PACA; RA $\vee R O$ ).
\end{abstract}

Conclusions: This information will assist in understanding the genomic factors regulating the influence of diet restriction on fertility and may assist in optimising nutritional and management systems for the improvement in reproductive performance.

Keywords: mRNAseq, Bovine, Hypothalamus, Energy homeostasis, Reproduction, Dietary restriction

\footnotetext{
* Correspondence: sinead.waters@teagasc.ie

${ }^{3}$ Animal and Bioscience Research Department, Animal and Grassland

Research and Innovation Centre, Teagasc, Grange, Dunsany, Co. Meath,

Ireland

Full list of author information is available at the end of the article
}

(c) The Author(s). 2017 Open Access This article is distributed under the terms of the Creative Commons Attribution 4.0 International License (http://creativecommons.org/licenses/by/4.0/), which permits unrestricted use, distribution, and reproduction in any medium, provided you give appropriate credit to the original author(s) and the source, provide a link to the Creative Commons license, and indicate if changes were made. The Creative Commons Public Domain Dedication waiver (http://creativecommons.org/publicdomain/zero/1.0/) applies to the data made available in this article, unless otherwise stated. 


\section{Background}

Over the decades great emphasis has been placed on selective breeding for milk yield in dairy cows resulting in cows being unable to meet the energy demands of maintenance and lactation with consequential mobilisation of body reserves to meet these demands. Such cows are described as being in NEB. Excessive and/or prolonged NEB negatively impacts on reproductive performance and increases the cows' susceptibility to disease [1]. During periods of severe NEB, animals are forced to channel available energy toward survival and away from processes such as reproduction [2]. Normal ovarian function is therefore delayed in such animals until the energy deficit is at least partially corrected. There is also evidence that a proportion of animals will resume cyclicity sooner than others despite all animals being at a similar energy balance [3, 4]. Mackey et al. [5] reported that some animals will continue to ovulate, while others will become anovulatory when placed on a severely restricted diet despite no differences in weight or body condition score $(\mathrm{BCS})$ at the beginning of a feeding phase.

Hormones such as insulin [6], IGF-1 [7], GH [8] leptin [9], and nutrients such as glucose [6] and fatty acids [9] have been implicated in signalling nutritional status. These signals act within the hypothalamus to regulate feed intake, energy expenditure and neuroendocrine functions including reproduction [10-12]. The hypothalamus is central to the neural control of homeostasis. Neurons in the hypothalamus are responsive to changes in metabolic status $[12,13]$ and appear to play an important role in mediating the effects of nutrition on reproduction via the hypothalamic-pituitary ovarian axis [14]. Gonadotrophin releasing hormone $(\mathrm{GnRH})$ is the primary reproductive hormone secreted from the hypothalamus that integrates a multitude of internal and environmental cues to regulate the secretion of luteinizing hormone $(\mathrm{LH})$ and follicle stimulating hormone (FSH) from the anterior pituitary gland [15].

The effects of nutrition on reproduction are most likely mediated through the hypothalamic-pituitaryovarian axis [16]. We have developed a short term dietary restriction heifer model facilitating animals to be characterised as sensitive or tolerant to an energy deficit based on their ability to ovulate while fed a restricted diet [17]. Approximately a third of heifers became anoestrous due to diet restriction. As expected, follicular growth rate and maximum diameter were reduced by diet restriction, with larger dominant follicles more likely to ovulate. Walsh et al. [18] showed that dietary restriction altered gene expression in the dominant follicle of the ovary potentially leading to reduced oestradiol synthesis, FSH-responsiveness and IGF signalling in granulosa, and LH-responsiveness in theca cells of dominant follicles. Furthermore, steroid biosynthesis within developing follicles was also altered suggesting that cholesterol transport into mitochondria to initiate steroidogenesis was affected [19].

Genes expressed in the hypothalamus are suggested to be involved in processing estrous behaviour in cattle [20, 21]. While candidate gene expression studies have been performed [13, 17], there are no published studies on the application of RNAseq to analyse hypothalamic tissue of individual animals in response to diet restriction. Thus the objective of this study was to compare differences in transcriptional profiles in hypothalamic tissue between these two groups of animals in an energy deficit but with divergent reproductive performance, and to a third control group on a higher level of feeding using RNAseq and pathway analysis.

\section{Results}

Transcriptional profile of the bovine hypothalamus On average close to 25.5 million fragments were sequenced for each sample. Of these 16 million, or approximately $60 \%$, were mapped to the bovine genome by bowtie (Table 1). On average, 9 million mapped reads remained after filtering out reads with more than 1 alignment to the genome and reads that mapped to exactly the same position on the genome (i.e. putative PCR duplicates). Approximately 4 million reads per sample were mapped to annotated exons by HTseq. An overview of these data is given in Table 1. Following exclusion of genes with fewer than 5 reads for one sample in any of the 3 groups, 15,295 genes were detected as expressed. The RNAseq data have been deposited in NCBI's Gene Expression Omnibus [22] and are accessible through GEO Series accession number GSE49540.

\section{Identification of significantly differentially expressed (SDE) genes}

Three comparisons of differential gene expression were carried out. These were RA v C, RA v RO, and RO v C. $\mathrm{SDE}$ genes were called at a false discover rate (FDR) of 0.1 using the DEseq package in $\mathrm{R}$, which models data as a negative binomial distribution. After statistical analysis

\begin{tabular}{|c|c|}
\hline Process & \\
\hline Total sequenced fragments & $25,512,814$ \\
\hline Fragments mapped to nuclear genome & $16,035,986$ \\
\hline Percentage mapped & $62.9 \%$ \\
\hline Uniquely mapped fragments & $12,655,723$ \\
\hline Percentage uniquely mapped & $78.9 \%$ \\
\hline Fragments without duplicates & $9,436,348$ \\
\hline Fragments mapped to annotated genes & $3,888,758$ \\
\hline
\end{tabular}


with DEseq a total of 69 genes had increased expression and 68 displayed decreased expression in the RA relative to C comparison (Additional file 1: Table S1). Fifteen genes had increased expression and 17 had decreased expression in the $\mathrm{RO}$ relative to $\mathrm{C}$ comparison (Additional file 2: Table S2). The comparison with the greatest number of SDE genes was RA v RO where 351 genes were observed to have increased expression and 743 decreased expression in the RA relative to $\mathrm{RO}$ comparison (Additional file 3: Table S3).

\section{Pathway analysis}

To gain insights into the biological processes occurring in the hypothalamus that result in anovulation due to diet restriction, three gene ontology and pathway analysis tools were applied. These included GOseq, Innatedb and Ingenuity Pathway Analysis.

\section{GOseq}

Enrichment of SDE genes in gene ontology (GO) terms was tested. GO annotations of genes with a FDR $<0.1$ from DEseq analysis were tested against all gene annotations in the GOseq database. $145 \mathrm{GO}$ terms were enriched $(P<0.01)$ in the comparison between RA and C. $47 \mathrm{GO}$ terms were enriched $(\mathrm{P}<0.01)$ between $\mathrm{RO}$ and C. And finally, 238 GO terms were enriched $(\mathrm{P}<0.01)$ when RA and RO were compared. The top 10 GO terms for each comparison are listed in Table 2.

\section{Innatedb}

SDE genes were normalised for gene length bias and were then mapped to the Innatedb database for pathway analysis using GOseq. From this mapping, a total of 12, 15, and 6 genetic pathways were found to be enriched $(\mathrm{P}<0.01)$ in the RA $\vee \mathrm{C}, \mathrm{RO} \vee \mathrm{C}$, and RA $\vee \mathrm{RO}$ comparisons, respectively. Only 16 and $6 \mathrm{SDE}$ genes resulted in the enrichment of these pathways in the RA v C and RO $\mathrm{v} \mathrm{C}$ comparisons. However, $58 \mathrm{SDE}$ genes resulted in 6 enriched pathways in the RA $v$ RO comparison. The small number of SDE genes resulting in a number of pathways becoming enriched was due to genes being present in multiple pathways. Pathways representing each comparison are listed in Tables 3, 4 and 5.

\section{Ingenuity pathway analysis}

To determine the molecular changes occurring that result in a proportion of heifers to become anovulatory, a 2nd gene ontology tool, Ingenuity Pathway Analysis (IPA), was used to analyse gene expression data. IPA returned a total of 9, 1 and 11 canonical pathways for RA v C, RO v C and RA v RO comparisons (Table 6).
Table 2 Enriched GO terms for all comparisons

\begin{tabular}{|c|c|c|}
\hline Go Term & Ontology $^{a}$ & $P$ value \\
\hline \multicolumn{3}{|l|}{ Restricted Anovulatory v Control } \\
\hline Defense response & $\mathrm{bp}$ & 4.79E-09 \\
\hline $\begin{array}{l}\text { Type I interferon-mediated signaling } \\
\text { pathway }\end{array}$ & $\mathrm{bp}$ & $1.15 \mathrm{E}-06$ \\
\hline Cellular response to type I interferon & $\mathrm{bp}$ & $1.15 \mathrm{E}-06$ \\
\hline Response to type I interferon & $\mathrm{bp}$ & $1.29 \mathrm{E}-06$ \\
\hline Response to other organism & $\mathrm{bp}$ & $1.70 \mathrm{E}-06$ \\
\hline Immune response & $\mathrm{bp}$ & $3.71 \mathrm{E}-06$ \\
\hline Response to biotic stimulus & $\mathrm{bp}$ & $3.96 \mathrm{E}-06$ \\
\hline Response to virus & $\mathrm{bp}$ & 5.36E-06 \\
\hline Innate immune response & $\mathrm{bp}$ & 5.47E-06 \\
\hline Gated channel activity & $\mathrm{mf}$ & $8.57 \mathrm{E}-06$ \\
\hline \multicolumn{3}{|l|}{ Restricted Ovulatory v Control } \\
\hline $\begin{array}{l}\text { Establishment of synaptic specificity at } \\
\text { neuromuscular junction }\end{array}$ & $\mathrm{bp}$ & 0.001550394 \\
\hline Collagen type XV & $\mathrm{cc}$ & 0.001734458 \\
\hline Cell-cell adherens junction & $\mathrm{CC}$ & 0.001885389 \\
\hline $\begin{array}{l}\text { Cellular component disassembly at cellular } \\
\text { level }\end{array}$ & $\mathrm{bp}$ & 0.002858457 \\
\hline Cellular component disassembly & $\mathrm{bp}$ & 0.002995423 \\
\hline $\begin{array}{l}\text { Macrophage colony-stimulating factor } \\
\text { receptor binding }\end{array}$ & $\mathrm{mf}$ & 0.003064441 \\
\hline Endothelial cell-cell adhesion & $\mathrm{bp}$ & 0.003122893 \\
\hline $\begin{array}{l}\text { Thyroid-stimulating hormone receptor } \\
\text { activity }\end{array}$ & $\mathrm{mf}$ & 0.003136574 \\
\hline Myoblast migration & $\mathrm{bp}$ & 0.003153657 \\
\hline $\begin{array}{l}\text { Transforming growth factor beta receptor } \\
\text { complex assembly }\end{array}$ & $\mathrm{bp}$ & 0.003216917 \\
\hline \multicolumn{3}{|l|}{ Restricted Ovulatory v Restricted Anovulatory } \\
\hline Neuron projection & $\mathrm{cc}$ & $6.75 \mathrm{E}-09$ \\
\hline Cell periphery & $\mathrm{cC}$ & $2.54 \mathrm{E}-08$ \\
\hline Plasma membrane & $\mathrm{CC}$ & $3.71 \mathrm{E}-08$ \\
\hline $\begin{array}{l}\text { G-protein coupled receptor protein } \\
\text { signaling pathway }\end{array}$ & $\mathrm{bp}$ & $1.87 \mathrm{E}-07$ \\
\hline Receptor activity & $\mathrm{mf}$ & $1.18 \mathrm{E}-06$ \\
\hline Signal transducer activity & $\mathrm{mf}$ & $1.20 \mathrm{E}-06$ \\
\hline Molecular transducer activity & $\mathrm{mf}$ & $1.20 \mathrm{E}-06$ \\
\hline Dendrite & $\mathrm{cc}$ & 1.85E-06 \\
\hline $\begin{array}{l}\text { Cell surface receptor linked signaling } \\
\text { pathway }\end{array}$ & $\mathrm{bp}$ & 7.16E-06 \\
\hline Intrinsic to membrane & $\mathrm{cc}$ & $9.48 \mathrm{E}-06$ \\
\hline
\end{tabular}

${ }^{\mathrm{a}}$ Gene ontology terms: bp: biological process; mf: molecular function; cc: cellular component

\section{Discussion}

Notable variation exists in the tolerance to NEB between individual cows with some animals displaying sensitivity and fail to cycle while other animals remain tolerant and 
Table 3 Enriched genetic pathways between Restricted Anovulatory and Control groups from Innatedb

\begin{tabular}{|c|c|c|c|}
\hline Pathway name & Genes & $\begin{array}{l}\text { Total no. of genes } \\
\text { in pathway }\end{array}$ & $P$ value \\
\hline RIG-I-like receptor signaling pathway & 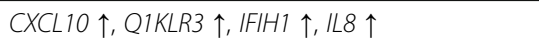 & 70 & 0.000815541 \\
\hline $\begin{array}{l}\text { Activation of NMDA receptor upon glutamate binding and } \\
\text { postsynaptic events }\end{array}$ & $A D C Y 1 \downarrow, G R I N 2 A \downarrow, G R I N 2 C \downarrow$ & 32 & 0.002998833 \\
\hline Post NMDA receptor activation events & $A D C Y 1 \downarrow, G R I N 2 A \downarrow, G R I N 2 C \downarrow$ & 32 & 0.002998833 \\
\hline Long-term potentiation & $A D C Y 1 \downarrow, G R I N 2 A \downarrow, G R I N 2 C \downarrow$, ITPR1 $\downarrow$ & 68 & 0.003241851 \\
\hline Cytosolic DNA-sensing pathway & $C X L 10 \uparrow, Q 1 K L R 3 \uparrow, Z B P 1 \uparrow$ & 55 & 0.003482075 \\
\hline Transmission across Chemical Synapses & $A D C Y 1 \downarrow, G R I N 2 A \downarrow, G R I N 2 C \downarrow, S L C 6 A 3 \downarrow$ & 76 & 0.00456686 \\
\hline Synaptic Transmission & $A D C Y 1 \downarrow, G R I N 2 A \downarrow, G R I N 2 C \downarrow, S L C 6 A 3 \downarrow$ & 81 & 0.005631178 \\
\hline Gata3 participate in activating the th2 cytokine genes expression & $A D C Y 1 \downarrow, I L 1 A \uparrow$ & 18 & 0.007137619 \\
\hline D-Arginine and D-ornithine metabolism & $D A O \downarrow$ & 1 & 0.007150141 \\
\hline Neuroactive ligand-receptor interaction & $\begin{array}{l}\text { CALRL } \uparrow, A 6 Q Q P 6 \uparrow, \text { GRIK3 } \downarrow \text {, GRIN2A } \downarrow \text {, GRIN2C } \\
\downarrow, T R Y 2 \uparrow\end{array}$ & 301 & 0.009258012 \\
\hline $\begin{array}{l}\text { Neuroransmitter Receptor Binding And Downstream Transmission } \\
\text { In The Postsynaptic Cell }\end{array}$ & $A D C Y 1 \downarrow, G R I N 2 A \downarrow, G R I N 2 C \downarrow$ & 48 & 0.009603978 \\
\hline Unblocking of NMDA receptor, glutamate binding and activation & GRIN2A $\downarrow$, GRIN2C $\downarrow$ & 12 & 0.009663882 \\
\hline
\end{tabular}

Expression is Restricted Anovulatory relative to Control. eg. CXL10 $\uparrow$ means RA has increased expression compared to C

continue to cycle [5]. The aim of this study was to establish the global shifts in gene expression profiles which contribute to animals becoming anovulatory following a period of dietary restriction. Results from the current study are discussed below under the following three comparisons: $\mathrm{RA} \vee \mathrm{C}, \mathrm{RA} \vee \mathrm{RO}$, and $\mathrm{RO} \vee \mathrm{C}$. Within the comparisons, the main over-represented pathway functions appear to be immune response (RA v $\mathrm{C}$ and $\mathrm{RA} v$ $\mathrm{RO})$; energy homeostasis ( $\mathrm{RA} v \mathrm{RO}$ ); and prevention of $\mathrm{GnRH}$ release (RA v RO).

\section{Restricted Ovulatory v Control Cellular motility}

Of the $6 \mathrm{SDE}$ genes resulting in pathway enrichment for the $\mathrm{RO} \vee \mathrm{C}$ comparison, down regulation of 3 of these genes increases cellular motility. CADH1, DSP and TSP4 all exhibited reduced expression in $\mathrm{RO}$ relative to $\mathrm{C}$. $C A D H 1$ is a cadherin that encodes a cell-cell adhesion glycoprotein, therefore reduced expression of this gene decreases the strength of cellular adhesion thus increasing cellular motility. DSP encodes desmoplakin, a

Table 4 Enriched genetic pathways between Restricted Ovulatory and Control groups from Innatedb

\begin{tabular}{|c|c|c|c|}
\hline Pathway name & Genes & Total no. of genes in pathway & $P$ value \\
\hline Apoptotic cleavage of cell adhesion proteins & $C A D H 1 \downarrow, D S P \downarrow$ & 11 & 7.81E-05 \\
\hline Immunoregulatory interactions between a Lymphoid and a non-Lymphoid cell & CADH1 $\downarrow, Q 05 B 55 \downarrow$, & 74 & 0.001265006 \\
\hline Apoptotic cleavage of cellular proteins & $C A D H 1 \downarrow, D S P \downarrow$ & 36 & 0.001499709 \\
\hline Arf6 trafficking events & $C A D H 1 \downarrow, T S H R \downarrow$ & 39 & 0.001743312 \\
\hline Apoptotic execution phase & $C A D H 1 \downarrow, D S P \downarrow$ & 42 & 0.001980774 \\
\hline Proteinase-activated receptor G (12/13) cascade & PAR1 $\downarrow$ & 3 & 0.003148078 \\
\hline Thrombin-mediated activation of PARs & PAR1 $\downarrow$ & 4 & 0.004671547 \\
\hline Platelet Activation & PAR $1 \downarrow, T S P 4 \downarrow$ & 95 & 0.005884444 \\
\hline Signaling by GPCR & PAR $\downarrow \downarrow, T S H R \downarrow$ & 648 & 0.006837614 \\
\hline Classical antibody-mediated complement activation & Q05B55 $\downarrow$ & 24 & 0.007641167 \\
\hline Proteinase-activated receptor G (q) cascade & PAR1 $\downarrow$ & 6 & 0.007793549 \\
\hline Thrombin signalling G-protein cascades & PAR1 $\downarrow$ & 6 & 0.007793549 \\
\hline Sumoylation as a mechanism to modulate ctbp-dependent gene responses & $\mathrm{CADH1} \downarrow$ & 8 & 0.008891268 \\
\hline Formation of Platelet plug & PAR1 $\downarrow$, TSP4 $\downarrow$ & 114 & 0.00923053 \\
\hline Thrombin signalling through PARs & PAR1 $\downarrow$ & 7 & 0.009310227 \\
\hline
\end{tabular}

Expression is Restricted Ovulatory relative to Control. eg. CADH1 $\downarrow$ means RO has decreased expression of this compared to $\mathrm{C}$ 
Table 5 Enriched genetic pathways between Restricted Anovulatory and Restricted Ovulatory groups from Innatedb

\begin{tabular}{|c|c|c|c|}
\hline Pathway name & Genes & $\begin{array}{l}\text { Total no. of genes } \\
\text { in pathway }\end{array}$ & $P$ value \\
\hline $\begin{array}{l}\text { Neuroactive ligand-receptor } \\
\text { interaction }\end{array}$ & 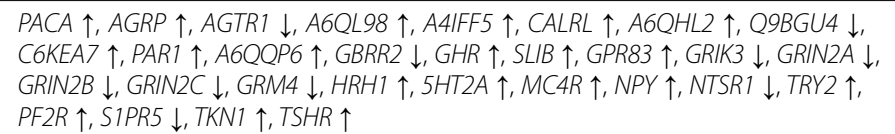 & 301 & 0.000211925 \\
\hline Toll-like receptor signaling pathway & $\begin{array}{l}\text { Q2LGB8 } \uparrow, C D 14 \uparrow, \text { Q1JPC5 } \uparrow, C X L 10 \uparrow, C X C L 9 \uparrow, F A D D \downarrow, I L 1 B \uparrow, A 6 Q Q K 2 \downarrow, \\
\text { PIK3CD } \downarrow \text {, A4IFU4 } \uparrow, T L R 2 \uparrow, T L R 3 \uparrow, T L R 4 \uparrow\end{array}$ & 101 & 0.00365653 \\
\hline Caspase 8 activation signalling & Q2LGB8 $\uparrow, F A D D \downarrow$ & 2 & 0.004011647 \\
\hline Systemic lupus erythematosus & $\begin{array}{l}\text { Q3SYT3 } \uparrow, C 1 S \uparrow, \text { Q1JPC5 } \uparrow, F C G R 2 \uparrow, F C G R 3 \uparrow, \text { GRIN2A } \downarrow \text {, GRIN2B } \downarrow \text {, Q17QG8 } \downarrow \text {, } \\
R O 52 \uparrow\end{array}$ & 95 & 0.004188484 \\
\hline Signaling by GPCR & 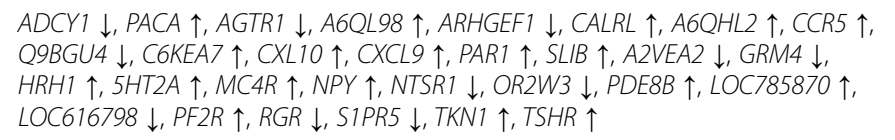 & 648 & 0.004475761 \\
\hline Class A/1 (Rhodopsin-like receptors) & $\begin{array}{l}\text { AGTR1 } \downarrow, A 6 Q L 98 \uparrow, A 6 Q H L 2 \uparrow, C C R 5 \uparrow, C X L 10 \uparrow, C X C L 9 \uparrow, P A R 1 \uparrow, A 2 V E A 2 \downarrow \\
H R H 1 \uparrow, 5 H T 2 A \uparrow, M C 4 R \uparrow, N P Y \uparrow, N T S R 1 \downarrow, L O C 785870 \uparrow, P F 2 R \uparrow, R G R \downarrow, S 1 P R 5 \downarrow \text {, } \\
\text { TKN1 } \uparrow, T S H R \uparrow\end{array}$ & 222 & 0.006932285 \\
\hline
\end{tabular}

Expression is Restricted Anovulatory relative to Restricted Ovulatory. eg. PACA $\uparrow$ means expression is higher in RA compared to RO

desmosome which occurs at intercellular junctions that tightly link adjacent cells. TSP4 encodes thrombospondin 4, an adhesive glycoprotein that mediates cell to cell interactions. Cellular motility or neuronal plasticity have previously been up-regulated in rodents when diet was reduced, and it has been suggested that this may contribute to a neuroprotective role in animals undergoing reduced dietary intake, as these processes are important in both learning and memory [23-25]. Another gene with decreased expression in $\mathrm{RO}$ relative to $\mathrm{C}$ was $P A R$ 1. Activation of either PAR-1 or PAR-2 may also have a neuroprotective effect $[26,27]$, and this is believed to be due to mesotrypsinogen/trypsinogen IV activation. However, no trypsinogen gene displayed increased expression in $\mathrm{RO} v \mathrm{C}$. It is therefore possible that there is less of a neuroprotective effect of diet restriction on the RO group. This is further compounded by the fact that neither $I L-1 \alpha$ nor $I L-1 \beta$ were differentially expressed in RO relative to $C$, indicating that the $R O$ group were not forced to choose between survival and protection of the brain or reproduction.

Thyroid stimulating hormone receptor (TSHR) had decreased expression in $\mathrm{RO} v \mathrm{C}$. Thyroid stimulating hormone (TSH) binds to TSHR, as does thyroid releasing hormone (TRH) to regulate the secretion of the thyroid hormones through a negative feedback loop. The thyroid hormones (T3 and T4) increase metabolism, growth and proliferation. Stimulation of TSHR can result in increased secretion of thyroid hormones. It is therefore possible that TSHR has reduced expression in RO to prevent the secretion of T3 and T4 which would use up energy that the RO group may not have had. This shows that the RO group were under a certain amount of pressure from the diet restriction but not to the same extent as RA. All animals will become anovulatory eventually under severe long term diet restriction and perhaps reduced expression of TSHR in order to save available energy occurs at the beginning of the process in the shift to anovulation.

\section{Restricted Anovulatory v Control \\ Immune response}

Signals generated by the hypothalamic-pituitary-gonadal (HPG) axis powerfully modulate immune system function [28]. Following pathway analysis the most overrepresented pathway within the $\mathrm{RA} v \mathrm{C}$ comparison was RIG-I-like receptor signalling pathway of which four genes (CXCL10, Q1KLR3, IFIH1, and IL8), all of which have roles in immune function, were up-regulated in RA relative to $\mathrm{C}$. The gene, CXCL10 encodes a chemokine of the CXC subfamily which binds to CXCR3. Binding of the CXCL10 protein to CXCR3 results in pleiotropic effects, including stimulation of monocytes, natural killer and T-cell migration, and modulation of adhesion molecule expression. It has been suggested that along with the significant role chemokines play in immune response, they may be added to the multiple peptides involved in the regulation of neuroendocrine pathways [29].

Both CXCL1O and IL8, had increased expression in RA relative to $C$ and have proven functions in reducing feed intake in rats [30]. In addition, $I L 1 \alpha$, another immune functioning gene, had increased expression in RA $\mathrm{v} C$. There are two forms of IL-1, IL- $1 \alpha$ and IL- $1 \beta$, and in most studies their biological activities are indistinguishable [31]. Both versions of IL-1 also bind to the same active receptor, IL-1R [31]. IL-1 has an anorexic effect in rats by stimulating the release of corticotropin releasing factor (CRF) in the hypothalamus [32], which acts to re-

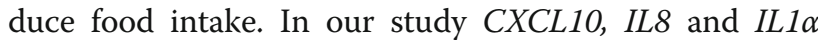


Table 6 Enriched genetic pathways in all comparisons from in IPA

\begin{tabular}{|c|c|c|c|}
\hline Pathway name & Genes & $\begin{array}{l}\text { Total no. of genes } \\
\text { in pathway }\end{array}$ & $P$ value \\
\hline \multicolumn{4}{|l|}{ Restricted Anovulatory v Control } \\
\hline $\begin{array}{l}\text { Activation of IRF by Cystosolic Pattern } \\
\text { Recognition Receptors }\end{array}$ & DDX58 $\uparrow, I F I H 1 \uparrow, I F I T 2 \uparrow, Z B P 1 \uparrow$ & 72 & 0.00073 \\
\hline Interferon Signalling & IFIT1 $\uparrow$, IFIT3 $\uparrow, M X 1 \uparrow$ & 36 & 0.00135 \\
\hline $\begin{array}{l}\text { Role of Hypercytokinemia/hyperchemokinemia } \\
\text { in the Pathogenesis of } \\
\text { Influenza }\end{array}$ & $C X C L 10 \uparrow, I L 8 \uparrow, I L 1 A \uparrow$ & 44 & 0.00286 \\
\hline Synaptic Long Term Potentiation & $A D C Y 1 \downarrow, G R I N 2 A \downarrow, G R I N 2 C \downarrow$, ITPR1 $\downarrow$ & 114 & 0.00461 \\
\hline CREB Signalling in Neurons & $A D C Y 1 \downarrow, G R I K 3 \downarrow, G R I N 2 A \downarrow, G R I N 2 C \downarrow$, ITPR1 $\downarrow$ & 202 & 0.00515 \\
\hline Calcium Signalling & CHRNA2 $\downarrow$, GRIN2A $\downarrow$, GRIN2C $\downarrow, I T P R 1 \downarrow$, MYH11 $\uparrow$ & 207 & 0.00541 \\
\hline Glutamate Receptor Signalling & GRIK3 $\downarrow$, GRIN2A $\downarrow$, GRIN2C $\downarrow$ & 69 & 0.00595 \\
\hline D-arginine and D-ornithine Metabolism & $D A O \downarrow$ & 18 & 0.00646 \\
\hline $\begin{array}{l}\text { Glycosphingolipid Biosynthesis - } \\
\text { Neolactoseries }\end{array}$ & ST3GAL6 $\uparrow, S T 8 S I A 5 \downarrow$ & 64 & 0.00957 \\
\hline \multicolumn{4}{|l|}{ Restricted Ovulatory v Control } \\
\hline Ga12/13 Signalling & $\mathrm{CDH} 1 \downarrow, F 2 R \downarrow$ & 128 & 0.00767 \\
\hline \multicolumn{4}{|l|}{ Restricted Anovulatory v Restricted Ovulatory } \\
\hline LXR/RXR Activation & $\begin{array}{l}A P O A 4 \downarrow \text {, CCL2 } \uparrow, C D 14 \uparrow, I L 1 A \uparrow, I L 1 B \uparrow, M S R 1 \uparrow, N R 1 H 2 \downarrow, P T G S 2 \uparrow, \\
R X R G \uparrow, S R E B F 1 \downarrow, T L R 3 \uparrow, T L R 4 \uparrow\end{array}$ & 93 & 0.000344 \\
\hline Germ Cell-Sertoli Cell Junction Signaling & 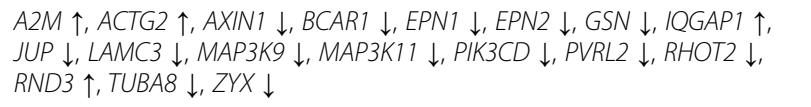 & 167 & 0.000870 \\
\hline TREM1 Signaling & CASP5 $\uparrow, C C L 2 \uparrow, C D 86 \uparrow$, FCGR2B $\uparrow, I C A M 1 \uparrow, I L 1 B \uparrow, T L R 2 \uparrow, T L R 3 \uparrow, T L R 4 \uparrow$ & 66 & 0.00125 \\
\hline $\begin{array}{l}\text { Neuropathic Pain Signaling In Dorsal Horn } \\
\text { Neurons }\end{array}$ & 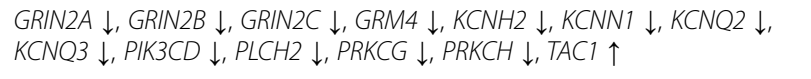 & 108 & 0.00133 \\
\hline $\begin{array}{l}\text { Hepatic Fibrosis / Hepatic Stellate Cell } \\
\text { Activation }\end{array}$ & $\begin{array}{l}\text { A2M } \uparrow, A G T R 1 \downarrow, C C L 2 \uparrow, C C R 5 \uparrow, C D 14 \uparrow, C X C L 9 \uparrow, F L T 1 \uparrow, I C A M 1 \uparrow, \\
\text { IGFBP5 } \downarrow, I L 1 A \uparrow, I L 1 B \uparrow, K D R \uparrow, M Y H 11 \uparrow, M Y H 14 \downarrow, \text { STAT1 } \uparrow, T L R 4 \uparrow\end{array}$ & 147 & 0.00159 \\
\hline Reelin Signalling in Neurons & $\begin{array}{l}\text { APBB } 1 \downarrow, \text { ARHGEF } 1 \downarrow, \text { ARHGEF10 } \downarrow, \text { ARHGEF16 } \downarrow, \text { CDK5R1 } \downarrow, \text { MAP3K9 } \downarrow \text {, } \\
\text { MAP3K } 11 \downarrow, \text { MAPK8IP } 1 \downarrow, \text { MAPK8IP3 } \downarrow, \text { PIK3CD } \downarrow, R E L N \uparrow\end{array}$ & 82 & 0.00175 \\
\hline G-Protein Coupled Receptor Signalling & 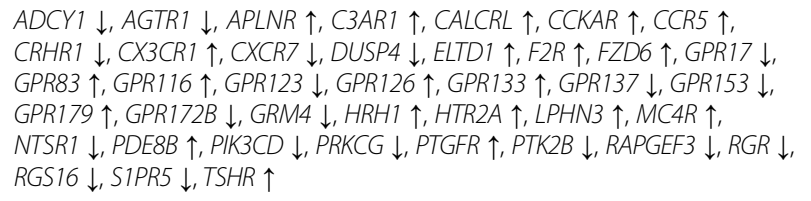 & 529 & 0.00314 \\
\hline Circadian Rhythm signalling & ADCYAP $1 \uparrow, C R Y 2 \downarrow$, GRIN2A $\downarrow$, GRIN2B $\downarrow$, GRIN2C $\downarrow, P E R 1 \downarrow$ & 35 & 0.00374 \\
\hline Axonal Guidance Signalling & 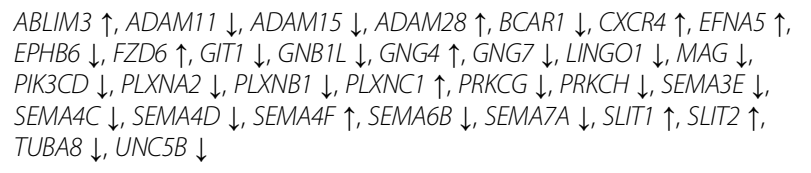 & 432 & 0.00706 \\
\hline Glycerolipid Metabolism & $\begin{array}{l}\text { ALDH1A1 } \downarrow \text {, ALDH4A } 1 \downarrow \text {, DAGLA } \downarrow \text {, DGAT2 } \uparrow, D G K Q \downarrow, \text { DHRS4 } \downarrow, \text { GLYCTK } \\
\downarrow, \text { LIPE } \downarrow, \text { LIPN3 } \downarrow, M G L L \downarrow, P P A P C \complement \downarrow\end{array}$ & 148 & 0.00798 \\
\hline Pathogenesis of Multiple Schlerosis & CCR5 $\uparrow, C X C L 9 \uparrow, C X C L 10 \uparrow$ & 9 & 0.00819 \\
\hline
\end{tabular}

were not responsible for reduced feed intake as dietary restriction was imposed upon experimental animals. However, the immune system has been shown to possess the ability to block normal reproductive functioning [33]. Both IL- $1 \beta$ and IL- $1 \alpha$ have been shown to suppress (through blocking GnRH secretion) and interfere with $\mathrm{LH}$ release, respectively [34, 35]. These results show that IL-1 is a strong suppressant of GnRH secretion and therefore reproduction, possibly explaining why an alteration in immune response genes was evident in RA compared to $\mathrm{C}$. 


\section{Neuroprotection}

An alternative reason for these immune genes to be switched on in the hypothalamus following diet restriction is that the energy deficit forces the body to decide between reproduction or immune function. In the tree lizard, albeit quite distant to the cow, when energy reserves are tight there is competition between immune function and reproduction [36]. The most important organ to the body's survival is the brain and so it is plausible that the immune genes mentioned have increased expression to facilitate a neuroprotective effect. It has been well documented in rodents that diet restriction increases longevity [37], but diet restriction is also known to have a neuroprotective effect [38, 39]. Much of this neuroprotection during diet restriction comes about from neurotrophins including BDNF [40, 41]; NT3 [41]; NGF and; NT-4/5, which promote the survival of neurons. None of these genes had increased expression in RA v C, however, IL-1 has been shown to stimulate the expression of NGF mRNA [42-45] possibly elucidating a mechanism whereby immune genes, particularly IL-1, are up-regulated in RA to protect the brain. It is very possible that the immune genes are carrying out both functions, preventing secretion of GnRH and performing a neuroprotective role to ensure the brain continues to function as a priority.

Further evidence to the body protecting the brain during diet restriction is the over expression of trypsinogen genes. In the RA v C comparison TRY2 and PRSS3 were over expressed. The PRSS3 gene encodes, due to alternative splicing, both mesotrypsinogen and trypsinogen 4 [46]. It has been proposed that mesotrypsinogen/trypsinogen IV, via activation of Proteinase-activated receptor 1 (PAR-1) or Proteinase-activated receptor 2 (PAR2 ), might contribute to neuroprotection in the rat brain [27]. Increased expression of trypsinogen was potentially carrying out a similar function and aiding neuroprotection during diet restriction.

\section{Restricted Anovulatory v Restricted Ovulatory Energy homeostasis}

It is interesting to note that although on the same restricted diet, the comparison between RA and RO returned the largest number of SDE. On initial analysis, there appears to be a considerable response in the hypothalamus to attempt to return the animal to a positive energy balance. $P A C A$, also known as $P A C A P$, was increased in RA relative to RO. This encodes adenylate cyclase activating polypeptide 1 , which acts as a neurotransmitter and neuromodulator. PACA stimulates insulin secretion from the pancreas in mice [47, 48], calves [49] and humans [50]. PACA also stimulates an increase in plasma vasopressin concentrations [51-53]. Vasopres$\sin$ is key to homeostasis as it regulates water, glucose and salt levels in the blood. Additionally, injection of PACA in the medial basal hypothalamus of ovariectomized ewe has been shown to suppress LH secretion and pulse frequency [54]. This action is presumably through an inhibition of GnRH. Increased PACA in the RA group may be preventing any LH secretion while also increasing the secretion of vasopressin to maximize blood glucose concentrations.

Two genes that potently increase food intake; $A g R P$ and NPY had increased expression in RA v RO. AgRP is almost exclusively expressed in the CNS $[55,56]$, where its gene product increases food intake as it acts as an antagonist to melanocortin-3 receptor (MC3R) and melanocortin-4 receptor (MC4R) [57, 58]. Activation of MC4R by its agonist $\alpha$-melanocyte-stimulating hormone $(\alpha-\mathrm{MSH})$, results in decreased food intake [59]. Consistent with this, $M C 4 R$ also had increased expression in RA v RO. Similar results have been observed previously in mice where $A g R P$ and $N P Y$ had increased hypothalamic expression during negative energy balance [60]. AgRP expressing neurons in the hypothalamus have been shown to express NPY [61], indicating a close working relationship between these neuropeptides in the hypothalamus. Recently, Allen et al. [13] showed marked differences in the expression of NPY and AGRP in the hypothalamus of heifers nutritionally programmed to hasten pubertal onset suggesting that they interact to regulate the reproductive neuroendocrine axis in cattle.

NPY is believed to be the most potent elicitor of food intake [62]. However, the literature provides evidence of both an inhibitory [63] and a stimulatory role [64] on LH secretion in rodents. NPY is believed to exert its effects on LH through GnRH [64-66] which is dose dependant and influenced by stage of cycle. In order for NPY to have an excitatory effect on GnRH release, intermittent hypothalamic NPY receptor activation is required, whereas continuous activation appears to inhibit LH release [67]. In the many studies on ovariectomized mammals, administration of NPY invariably causes an inhibition on GnRH levels [66, 68-71]. Therefore, in order for NPY to have a positive effect on GnRH, suitable ovarian steroid concentrations must exist and NPY receptor activation must be intermittent. If either of these factors are not satisfactory, NPY will suppress GnRH. The increased expression of NPY in RA heifers may chronically activate its receptor and therefore inhibit GnRH release. Furthermore, both estradiol and progesterone plasma concentrations were lowest in RA heifers [72] and may have contributed to NPY inhibiting GnRH.

Diet restriction or fasting increases hypothalamic NPY concentrations [71, 73] and mRNA [74] in sheep, and rats [75]. It is therefore surprising that RA had higher $N P Y$ expression than $\mathrm{RO}$ considering both groups were 
fed the same restricted diet. However, it has been previously observed in rats that peripheral insulin administration suppresses NPY release in the hypothalamic paraventricular nucleus (PVN) [76]. Additionally, central administration of insulin decreases both NPY mRNA and NPY concentrations in hypothalamic areas [77]. These findings suggest that the increase in NPY in response to fasting is dependent on low insulin levels. As documented in our previous study [72], using the same animals, insulin and IGF-1 concentrations were higher in $\mathrm{RO}$ compared to the two other groups on days -2 and 0 . As the feeding phase progressed concentrations of these hormones decreased in both RO and RA and were similar by day 9 and remained stable until slaughter. It is therefore likely that the reason RO heifers do not become anovulatory during diet restriction is that their initially higher insulin, and possibly IGF-1, concentrations prevent an increase in NPY at sufficiently high concentrations to inhibit GnRH. A considerable carry over effect of this was observed. All heifers had two opportunities to ovulate. Within RA four heifers ovulated the 1st dominant follicle (DF) but failed to ovulate the 2nd DF even though insulin and IGF-1 concentrations were lower in RA from the outset. This suggests that it takes some time for metabolic messages, possibly through NPY, to block GnRH in cattle. The prolonged time taken to prevent GnRH release may explain why RO heifers ovulated the 2nd DF even though insulin levels and IGF-1 levels were almost similar to RA heifers at that stage. NPY has been described as one of the essential messenger molecules that serve as a communication bridge between neural processes that regulate reproduction and energy homeostasis [67], and data from this study certainly supports that finding.

Other genes with roles in energy homeostasis had altered expression in the RA $\mathrm{v}$ RO comparison. AGTR1 which encodes type-1 angiotensin II receptor, functioning in salt and thirst desire had decreased expression in RA. A6QL98 encodes the apelin receptor which is similar to the angiotensin receptor. This receptor had increased expression in RA. Apelin increases water intake in rats following administration [78, 79]. It also has a diuretic effect which may work by decreasing vasopressin levels in the hypothalamus [80]. Apelin is also believed to exert an effect on food intake but its role is contradictory. Taheri et al. [79] found no effect of centrally administered apelin on food intake. However, another study found the exact opposite effect when apelin was centrally administered in rats [81]. One possible reason for this inconsistency is circadian rhythm. It has been observed in rats that i.c.v. injection of apelin during the night has a dose dependent reduction in food intake 2$4 \mathrm{~h}$ after injection. Yet, day-time administration of apelin to satiated rats stimulated feeding [82]. If apelin exerts an inhibitory effect on feed intake in cattle, it would be consistent with the theory that RA heifers have increased expression of certain genes in an attempt to stimulate food intake. This is due to the apelin receptor having increased expression perhaps reflecting that there was a decreased requirement for apelin stimulated food inhibition in RA.

Similarly, in our study, $A 6 Q H L 2$ encoding cholecystokinin-A receptor had increased expression in RA. A cholecystokinin-A receptor knock-out study in mice showed that cholecystokinin diminished food intake by up to $90 \%$ through its receptor [83]. The fact that the receptor had increased expression suggests that it was not activated in RA heifers therefore its food inhibition function did not occur. Q9BGU4 encodes the corticotropin releasing hormone receptor 1 (CRF-R1). This gene had reduced expression in RA $v$ RO. CRF inhibits food intake so possibly the CRF-R is reduced in RA so any CRF produced by stress response cannot fulfil its role in the reduction in food intake but can stimulate adrenocorticotropic hormone (ACTH) secretion. In contrast, C6KEA7 which encodes corticotropin releasing hormone receptor 2 had increased expression in RA. CRF is primarily involved in the stress response by stimulating the synthesis and release of $\mathrm{ACTH}$ from the anterior pituitary gland, which in turn stimulates the release of glucocorticoids from the adrenal gland. Cortisol levels rise during periods of fasting in humans [84], and this is presumably through an increase of CRF in the hypothalamus. Cortisol stimulates gluconeogenesis, particularly in the liver while also inhibiting glucose uptake in muscle and adipose tissue in order to conserve glucose levels. Data from our previous study [72] using the same animals, showed that glucose levels were unaffected by group suggesting a possible reason for this observation. Cortisol also stimulates lipolysis in adipose tissue. Both restricted groups, RA and RO, had elevated beta hydroxybutyrate (BHB) levels compared to $\mathrm{C}$, indicating a greater amount of lipolysis was occurring in these animals. There are therefore reasons for the CRF receptors to have increased expression in RO.

The fact that these genes (AgRP, NPY, MC4R, A6QL98, A6QHL2, Q9BGU4) which are heavily involved in increasing food intake were up-regulated in $\mathrm{RA}$ relative to $\mathrm{RO}$ even though both groups were on the same restricted individually fed diet reinforces that RA animals are in a greater energy deficit. All animals on a restricted diet will eventually come to a point where the decision must be made to cease reproductive functioning in order to increase the chances of survival. Data shows that RA are forced to make that decision sooner due to lower plasma IGF-1 and insulin levels, which are most probably due to underlying genetic variation in the animals. 


\section{Immune response}

The second observation from the data is that, similar to that observed in RA v C, there was a considerable immune response in RA relative to $\mathrm{RO}$. Genes such as $C X L 10, C X C L 9, I L-1 \beta$, and $I L-1 \alpha$ all had increased expression. This again was somewhat surprising as both groups were on the same diet. However, this proves that RA were in a deeper energy deficit than RO and therefore had to up-regulate immune genes for neuroprotection. $I L-1 \beta$ and $I L-1 \alpha$ were in the top $10 \%$ of increased fold change genes in RA relative to RO. TRY2 also had increased expression in RA and as mentioned trypsinogens in the brain are linked with neuroprotection. Due to the GnRH suppressant role of NPY it is more likely that the immune genes $I L-1 \alpha$ and $I L-1 \beta$ do not initially cause anovulation but rather add to the prevention of a re-initiation of the oestrous cycle by $\mathrm{GnRH}$, along with PACA and NTSR1.

\section{Prevention of GnRH secretion}

NTSR1 had reduced expression in RA heifers and this along with other SDE genes $I L 1 \alpha, I L 1 \beta, N P Y$ and PACA, may act as a method to reduce any LH surge in order to conserve all available energy for biological processes more important to survival. NTSR1 encodes neurotensin receptor 1 . Neurotensin has been implicated in the regulation of $\mathrm{GnRH} / \mathrm{LH}$ release. In the rat, $\mathrm{GnRH}$ neurons co-express mRNA for NTSR1, suggesting that GnRH neurons may be direct targets for activation by neurotensin [85]. It has also been observed that administration of neurotensin directly in the preoptic area of the hypothalamus evokes LH secretion [86, 87]. Furthermore, a blockade of neurotensin signalling reduces the LH surge in the rat [88]. In mice however, neurotensin is thought not to play a direct role in generating the $\mathrm{GnRH} / \mathrm{LH}$ surge but is regulated by E2 [89].

\section{Conclusions}

Evidence in this study indicates that heifers became anoestrus following a period of diet restriction. Biological processes affected by dietary restriction in hypothalami included immune response, neuroprotection, cell motility and energy homeostasis. Increased expression of molecules within the hypothalamus provided the $\mathrm{GnRH}$ neurons with information that body reserves were not adequate to continue oestrous cyclicity following restriction (Fig 1). There was a delay in this information being sent to the GnRH neurons in RO heifers due to higher initial concentrations of insulin and possibly IGF1. This was particularly true for NPY. The reasoning for RO heifers having higher IGF-1 and insulin concentrations than RA heifers on a similar level of feeding (days -2 and 0 ) requires more research. However, a possibility is a more efficient utilisation of feed due to underlying genetic variation. The findings presented here for the first time point to a possible molecular mechanism for increased tolerance to an energy deficit in the cow, and assist in the overall understanding of the effects of NEB on fertility in the cow.

\section{Methods}

All animal procedures performed in this study were conducted under experimental licence from the Irish Department of Health and Children (licence number B100/ 846).in accordance with the Cruelty to Animals Act 1876 and the European Communities (Amendment of Cruelty to Animals Act 1876) Regulation 2002 and 2005. Procedures were carried out in accordance with Regulation 12 of the European Communities Regulations 2006 S.I. 612 of 2006 and were sanctioned by the Research Ethics Committee, University College Dublin (UCD), Ireland.

\section{Experimental model}

A short term (18-day) dietary restriction model was developed which induced abrupt onset of anoestrus in some animals while others maintained oestrous cyclicity [17, 72]. Briefly, in that study 40 Charolais-crossbred heifers exhibiting regular oestrous cycles with an initial liveweight (mean \pm SEM) and BCS of $395 \pm 3.7 \mathrm{~kg}$, and $2.99 \pm 0.04$, respectively, were used. Oestrus was synchronised using an 8 day combined CIDR and prostaglandin $F_{2 \alpha}$ regimen. During the oestrous synchronisation period all heifers were fed a diet supplying 1.2 estimated maintenance energy requirements $(\mathrm{Mn})$. One day before CIDR removal (day 0), heifers were allocated randomly to either a diet supplying $0.4 \mathrm{Mn}(n=28)$ or retained on $1.2 \mathrm{Mn}(\mathrm{C}$; $n=12$ ). Following CIDR removal, ovarian follicular growth and ovulation were monitored using transrectal ultrasonography. On the 11th day after diet allocation, prostaglandin $\mathrm{F}_{2 \alpha}\left(\mathrm{PGF}_{2 \alpha}\right)$ was administered to induce luteolysis, oestrus and ovulation. Within $0.4 \mathrm{Mn}$, animals were classified as either restricted ovulatory $(\mathrm{RO})$ or restricted anovulatory (RA) depending on whether the DF ovulated or failed to ovulate, respectively. Heifers were blood sampled on days $-2,0-17$ and again at slaughter (day 18) for the metabolic hormones IGF-1, insulin, leptin, glucose, $\mathrm{BHB}$, and urea, and the reproductive hormones P4 and E2. After 18 days of feeding all heifers were slaughtered in a commercial abattoir and hypothalamic tissue was recovered. The procedure used for harvesting of hypothalamic tissue has been outlined previously by Matthews [72]. A subset of animals was used for this particular study which consisted of 20 animals (6 C, 7 RO, 7 RA).

\section{mRNA extraction}

Hypothalami were collected, immediately snap frozen in liquid nitrogen and subsequently stored at $-80{ }^{\circ} \mathrm{C}$. Total 


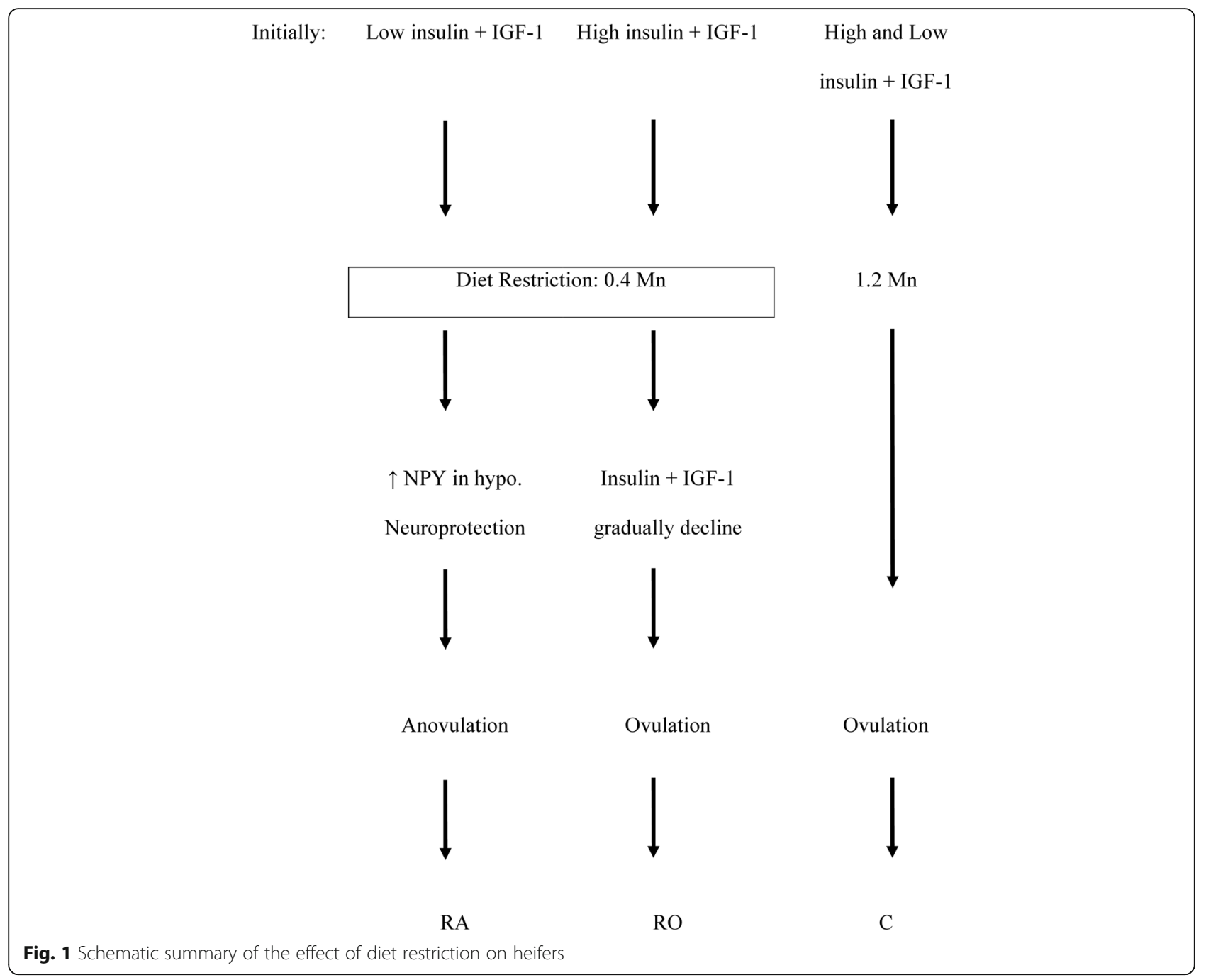

RNA was isolated using a lipid tissue midi kit (Qiagen Ltd., West Sussex, UK) which includes a DNase step to remove any genomic DNA contamination. RNA yield and quality were assessed using automated capillary gel electrophoresis on a Bioanalyzer 2100 with RNA 6000 Nano chips according to manufacturer's instructions (Agilent Technologies Ireland, Dublin, Ireland). Poly A messenger RNA (mRNA) was purified from $10 \mu \mathrm{g}$ total RNA using Dynal oligo (dT) magnetic beads (Invitrogen, Bio Sciences ltd., Dublin, Ireland). Oligo(dT) selection was performed twice to ensure minimal carry-over of ribosomal RNA (rRNA).

\section{cDNA preparation}

mRNA was fragmented and then reverse transcribed into cDNA. Zinc mediated fragmentation was performed by adding fragmentation reagent (Ambion, Applied Biosystems, Warrington, UK) to the mRNA and incubation at $70{ }^{\circ} \mathrm{C}$ for $5 \mathrm{~min}$. First strand cDNA synthesis was performed using $3 \mu \mathrm{g}$ of random hexamer primers and
SuperScript II (Invitrogen). After the first strand was synthesized, second strand synthesis buffer, dNTPs, RNase $\mathrm{H}$ and $E$. coli DNA polymerase I (Invitrogen) were added and incubated for $2.5 \mathrm{~h}$ at $16{ }^{\circ} \mathrm{C}$ to translate the second-strand synthesis. DNA was then purified using a Qiaquick PCR spin column (Qiagen) and eluted in $30 \mu \mathrm{l} \mathrm{EB}$ buffer (Qiagen).

\section{Library preparation}

The ends of cDNA fragments were repaired with a combination of T4 DNA polymerase (New England BioLabs, ISIS Ltd., Wicklow, Ireland) and E. coli DNA polymerase I Klenow fragment (New England BioLabs) which remove 3 '-overhangs and fill in 5 '-overhangs. A single ' $\mathrm{A}$ ' base was added to the 3 '-end of blunt phosphorylated cDNA fragments, using the polymerase activity of Klenow Exo fragment (New England BioLabs), to allow for the ligation of adaptors which have a single 3 '- $\mathrm{T}$ overhang. The ligated adaptors prepare the cDNA fragments to be hybridized to a flow cell. DNA was purified using 
gel electrophoresis to allow for templates of uniform length to be sequenced. Seventeen cycles of PCR enrichment was performed on the purified adaptor ligated cDNA templates. Adapter ligated cDNA fragment libraries were run on an Illumina GAII using version 3 sequencing and single read cluster generation kits capable of sequencing 42 bases of each template.

\section{Read alignment and abundance calculations}

RNA-seq reads from each flow cell lane were aligned separately to the Bos taurus genome (BCM4 genome assembly) [90] using the ultrafast short read aligner Bowtie version 0.12.5 [91]. Fastq output files from the sequencer were used as input. The following options were specified for bowtie processing: quality scores are ASCII characters equal to the Phred quality scores plus 64 (--Solexa1.3quals); the maximum number of mismatches allowed in the first 28 bases is $2(-n 2,-128)$; suppressing all alignments for any read that had more than 1 reportable alignment $(-\mathrm{m} 1)$; retained alignments were reported in SAM format $(-S)$.

Files were sorted according to location in the genome and any read duplicates were deleted in order to normalise for PCR bias. The software package HTseq (version 0.4.4p6) (http://pypi.python.org/pypi/HTSeq) was used to calculate raw counts of transcript coverage for all annotated genes from the ENSEMBL v59 annotation of the bovine genome [92]. The counts for all exons from the samples were collated into one file and any gene with fewer than 5 reads in all samples was excluded from the subsequent statistical analysis of differential gene expression.

\section{Identification of SDE genes and pathway analysis}

Statistical analysis of gene expression was carried out using DEseq (Version 1.1.11) [93] which uses a generalisation of the Poisson model, the negative binomial distribution, to model biological and technical variance and test for differential expression between two experimental conditions. The statistical tests were corrected for multiple testing using the Benjamini and Hochberg (BH) method [94] as implemented in $\mathrm{R}$ (version 2.12.0). SDE genes were called at a FDR of 0.1, and these were retained for further analysis. Reads were converted to their human orthologs for gene ontology. Data were normalised for gene length bias and genes were mapped to the Innatedb database [95] for pathway analysis using GOseq [96]. Data were also mapped to the IPA database to gather as much information as possible regarding molecular events occurring in the hypothalamus due to dietary restriction and its effect on reproductive performance in the bovine.

\section{Additional Files}

Additional file 1: Table S1. Description: Differentially expressed annotated genes between restricted anovulatory (RA) and control (C) groups. (DOCX $27 \mathrm{~kb}$ )

Additional file 2: Table S2. Description: Differentially expressed annotated genes between restricted ovulatory (RO) and control (C) groups. (DOCX $17 \mathrm{~kb}$ )

Additional file 3: Table S3. Description: Differentially expressed annotated genes between restricted anovulatory (RO) and restricted ovulatory (RO) groups. (DOCX $104 \mathrm{~kb}$ )

\section{Abbreviations}

ACTH: Adrenocorticotropic hormone; BCS: Body condition score; BH: Benjamini and Hochberg; BHB: Beta hydroxybutyrate; C: Control group; CIDR: Controlled internal drug-releasing device; CRF: Corticotropin releasing factor; DF: Dominant follicle; FDR: False discovery rate; FSH: Follicle stimulating hormone; GEO: Gene expression omnibus; GnRH: Gonadotrophin releasing hormone; GO: Gene ontology; HPG: Hypothalamic-pituitary-gonadal; i.c.v.: Intracerebroventricular; IGF-1: Insulin-like growth factor; IPA: Ingenuity pathway analysis; LH: Luteinizing hormone; MC3R: Melanocortin-3 receptor; MC4R: Melanocortin-4 receptor; $\mathrm{Mn}$ : Maintenance energy requirements; NEB: Negative energy balance; NPY: Neuropeptide Y; RA: Restricted anovulatory group; RO: Restricted ovulatory group; SDE: Significantly differentially expressed; TRH: Thyroid releasing hormone; TSH: Thyroid stimulating hormone; TSHR: Thyroid stimulating hormone receptor; a-MSH: a-melanocyte-stimulating hormone

\section{Acknowledgements}

The authors would like to thank staff at Teagasc Athenry for the management and care of the animals used in this study. D. Matthews was in receipt of a Teagasc Walsh Fellowship.

\section{Funding}

This work was funded through Teagasc Walsh Fellowship to Daragh Matthews (Project Number: RMIS 5756).

\section{Availability of data and materials}

The datasets generated during and analysed in the current study are available in the NCBI's Gene Expression Omnibus repository, and are accessible through GEO Series accession number GSE49540 [https:// www.ncbi.n/m.nih.gov/geo/query/acc.cgi].

\section{Authors' contributions}

$\mathrm{MD}, \mathrm{DK}$, and SW conceived the study and participated in its design and coordination and helped to draft the manuscript. MD, DK and DM performed the animal study. DM and SW performed the molecular analyses. DM, CC and KK performed bioinformatic, pathway and statistical analyses. DM and SW drafted the manuscript. All authors read and approved the final manuscript.

\section{Ethics approval}

All animal procedures performed in this study were conducted under experimental licence from the Irish Department of Health and Children in accordance with the Cruelty to Animals Act 1876 and the European Communities (Amendment of Cruelty to Animals Act 1876) Regulation 2002 and 2005, and in accordance with Regulation 12 of the European Communities Regulations 2006 S.I. 612 of 2006.

\section{Consent for publication}

Not applicable.

\section{Competing interests}

The authors declare that they have no competing interests.

\section{Publisher's Note}

Springer Nature remains neutral with regard to jurisdictional claims in published maps and institutional affiliations. 


\section{Author details}

'Animal and Grassland Research and Innovation Centre, Teagasc, Mellows Campus, Athenry, Co. Galway, Ireland. ${ }^{2}$ School of Agriculture and Food Science, University College Dublin, Belfield Dublin 4, Ireland. ${ }^{3}$ Animal and Bioscience Research Department, Animal and Grassland Research and Innovation Centre, Teagasc, Grange, Dunsany, Co. Meath, Ireland.

\section{Received: 25 July 2017 Accepted: 2 November 2017}

\section{Published online: 09 November 2017}

\section{References}

1. Lucy MC, Staples CR, Thatcher WW, Erickson PS, Cleale RM, Firkins JL, et al. Influence of diet composition, dry-matter intake, milk-production and energy-balance on time of postpartum ovulation and fertility in dairy-cows. Anim Prod. 1992;54:323-31.

2. Hill JW, Elmquist JK, Elias CF. Hypothalamic pathways linking energy balance and reproduction. Am J Physiol Endocrinol Metab. 2008;294:E827-32.

3. Konigsson K, Savoini G, Govoni N, Invernizzi G, Prandi A, Kindahl H, et al. Energy balance, leptin, NEFA and IGF-I plasma concentrations and resumption of post partum ovarian activity in Swedish red and white breed cows. Acta Vet Scand. 2008;50:3.

4. Lucy MC, Crooker BA. Physiological and genetic differences between low and high index dairy cows. BSAS occasional publication. Fertility in the High-Producing Dairy Cow. 2001;1:223-36.

5. Mackey DR, Sreenan JM, Roche JF, Diskin MG. Effect of acute nutritional restriction on incidence of anovulation and periovulatory estradiol and gonadotropin concentrations in beef heifers. Biol Reprod. 1999;61:1601-7.

6. Adam CL, Findlay PA. Inhibition of luteinizing hormone secretion and expression of c-fos and corticotrophin-releasing factor genes in the paraventricular nucleus during insulin-induced hypoglycaemia in sheep. J Neuroendocrinol. 1998;10:777-83.

7. Hiney JK, Ojeda SR, Dees WL. Insulin-like growth factor I: a possible metabolic signal involved in the regulation of female puberty. Neuroendocrinology. 1991;54:420-3.

8. Simpson RB, Armstrong JD, Harvey RW, Miller DC, Heimer EP, Campbell RM. Effect of active immunization against growth hormone-releasing factor on growth and onset of pubery in beef heifers. J Anim Sci. 1991;69:4914-24.

9. Garcia MR, Amstalden M, Morrison CD, Keisler DH, Williams GL. Age at puberty, total fat and conjugated linoleic acid content of carcass, and circulating metabolic hormones in beef heifers fed a diet high in linoleic acid beginning at four months of age. J Anim Sci. 2003;81:261-8.

10. Hiney JK, Srivastava V, Nyberg CL, Ojeda SR, Dees WL. Insulin-like growth factor I of peripheral origin acts centrally to accelerate the initiation of female puberty. Endocrinology. 1996;137:3717-28.

11. Zieba DA, Amstalden M, Morton S, Maciel MN, Keisler DH, Williams GL. Regulatory roles of leptin at the hypothalamic-hypophyseal axis before and after sexual maturation in cattle. Biol Reprod. 2004;71:804-12.

12. Stanley S, Wynne K, McGowan B, Bloom S. Hormonal regulation of food intake. Physiol Rev. 2005;85:1131-58.

13. Allen CC, Alves BR, Li X, Tedeschi LO, Zhou H, Paschal JC, et al. Gene expression in the arcuate nucleus of heifers is affected by controlled intake of high- and low-concentrate diets. J Anim Sci. 2012;90:2222-32.

14. Rapsoinho PD, Broqua P, Pierroz DD, Hayward A, Dumont Y, Quirion R, et al. Evidence that the inhibition of luteinizing hormone secretion exerted by central administration of neuropeptide Y (NPY) in the rat is is predominantly mediated by the NPY-Y5 receptor subtype. Endocrinology. 1999;140: 4046-55.

15. Smith MJ, Jennes L. Neural signals that regulate GnRH neurones directly during the oestrous cycle. Reproduction. 2001;122:1-10.

16. Nolan R, O'Callaghan D, Duby RT, Lonergan P, Boland MP. The influence of short-term nutrient changes on follicle growth and embryo production following superovulation in beef heifers. Theriogenology. 1998;50:1263-74.

17. Matthews D, Waters SM, Diskin MG, Kenny DA, Morris DG, Earley B. The effects of short term dietary restriction on haematological responses and leukocyte gene expression of anovulatory and ovulatory beef heifers. Res Vet Sci. 2015;98:145-53.

18. Walsh SW, Matthews D, Browne JA, Forde N, Crowe MA, Mihm M, et al. Acute dietary restriction in heifers alters expression of genes regulating exposure and response to gonadotrophins and IGF in dominant follicles. Anim Reprod Sci. 2012;133:43-51.
19. Walsh SW, Mehta JP, McGettigan PA, Browne JA, Forde N, Alibrahim RM, et al. Effect of the metabolic environment at key stages of follicle development in cattle: focus on steroid biosynthesis. Physiol Genomics. 2012:44:504-17.

20. Kommadath A, Woelders H, Beerda B, Mulder HA, de Wit AA, Veerkamp RF, et al. Gene expression patterns in four brain areas associate with quantitative measure of estrous behavior in dairy cows. BMC Genomics. 2011;12:200.

21. Hulsegge I, Woelders H, Smits M, Schokker D, Jiang L, Sorensen P. Prioritization of candidate genes for cattle reproductive traits, based on protein-protien interactions, gene expression, and text-mining. Physiol Genomics. 2013:45:400-6.

22. Goeman JJ, Buhlmann P. Analyzing gene expression data in terms of gene sets: methodological issues. Bioinformatics. 2007;23:980-7.

23. Idrobo F, Nandy K, Mostofsky DI, Blatt L, Nandy L. Dietary restriction: effects on radial maze learning and lipofuscin pigment deposition in the hippocampus and frontal cortex. Arch Gerontol Geriatr. 1987:6:355-62.

24. Ingram DK, Weindruch R, Spangler EL, Freeman JR, Walford RL. Dietary restriction benefits learning and motor performance of aged mice. J Gerontol. 1987:42:78-81.

25. Stewart J, Mitchell J, Kalant N. The effects of life-long food restriction on spatial memory in young and aged Fischer 344 rats measured in the eightarm radial and the Morris water mazes. Neurobiol Aging. 1989;10:669-75.

26. Luo W, Wang Y, Reiser G. Protease-activated receptors in the brain: receptor expression, activation, and functions in neurodegeneration and neuroprotection. Brain Res Rev. 2007;56:331-45.

27. Wang Y, Luo W, Reiser G. Trypsin and trypsin-like proteases in the brain: proteolysis and cellular functions. Cell Mol Life Sci. 2008;65:237-52.

28. Marchetti B, Gallo F, Farinella Z, Tirolo C, Testa N, Caniglia S, et al. Gender, neuroendocrine-immune interactions and neuron-glial plasticity. Role of luteinizing hormone-releasing hormone (LHRH). AnnN Y Acad Sci. 2000;917: 678-709.

29. Callewaere C, Banisadr G, Rostene W, Parsadaniantz SM. Chemokines and chemokine receptors in the brain: implication in neuroendocrine regulation. J Mol Endocrinol. 2007;38:355-63.

30. Plata-salaman CR, Borkoski JP. Chemokines/intercrines and central regualtion of feeding. Am J Phys. 1994;266:R1711-5.

31. Dinarello CA. Interleukin-1. Cytokine Growth Factor Rev. 1997:8:253-65.

32. Uehara A, Sekiya C, Takasugi Y, Namiki M, Arimura A. Anorexia induced by interleukin 1: involvement of corticotropin-releasing factor. Am J Phys. 1989; 257:R613-7.

33. Tomaszewska-Zaremba D, Herman A. The role of immunological system in the regulation of gonadoliberin and gonadotropin secretion. Reprod Biol. 2009:9:11-23.

34. Watanobe H, Hayakawa Y. Hypothalamic interleukin-1 beta and tumor necrosis factor-alpha, but not interleukin-6, mediate the endotoxin-induced suppression of the reproductive axis in rats. Endocrinology. 2003;144: 4868-75.

35. Rivier C, Vale W. Cytokines act within the brain to inhibit luteinizing hormone secretion and ovulation in the rat. Endocrinology. 1990;127: 849-56.

36. French SS, Johnston GIH, Moore MC. Immune activity suppresses reproduction in food-limited female tree lizards Urosaurus Ornatus. Funct Ecol. 2007;21:1115-22.

37. Sohal RS, Weindruch R. 1996. Oxidative stress, caloric restriction, and aging. Science. 1996;273:59-63.

38. Bruce-Keller AJ, Umberger G, Mcfall R, Mattson MP. Food restriction reduces brain damage and improves behavioral outcome following excitotoxic and metabolic insults. Ann Neurol. 1999:45:8-15.

39. ZF Y, Mattson MP. Dietary restriction and 2-deoxyglucose administration reduce focal ischemic brain damage and improve behavioral outcome: evidence for a preconditioning mechanism. J Neurosci Res. 1999;57:830-9.

40. Duan W, Guo Z, Mattson MP. Brain-derived neurotrophic factor mediates an excitoprotective effect of dietary restriction in mice. J Neurochem. 2001;76: 619-26.

41. Lee J, Seroogy KB, Mattson MP. Dietary restriction enhances neurotrophin expression and neurogenesis in the hippocampus of adult mice. J Neurochem. 2002;80:539-47.

42. Spranger M, Lindholm D, Bandtlow C, Heumann R, Gnahn H, Naher-Noe M, et al. Regulation of nerve growth factor (NGF) synthesis in the rat central nervous system: comparison between the effects of Interleukin-1 and 
various growth factors in Astrocyte cultures and in vivo. Eur J Neurosci. 1990;2:69-76.

43. Carman-Krzan M, Vige X, Wise BC. Regulation by interleukin-1 of nerve growth factor secretion and nerve growth factor mRNA expression in rat primary astroglial cultures. J Neurochem. 1991;56:636-43.

44. Friedman WJ, Larkfors L, Ayer-Lelievre C, Ebendal T, Olson L, Persson H. Regulation of beta-nerve growth factor expression by inflammatory mediators in hippocampal cultures. J Neurosci Res. 1990;27:374-82.

45. Friedman WJ, Thakur S, Seidman L, Rabson AB. Regulation of nerve growth factor mRNA by interleukin-1 in rat hippocampal astrocytes is mediated by NFkappaB. J Biol Chem. 1996;271:31115-20.

46. Toth J, Siklodi E, Medveczky P, Gallatz K, Nemeth P, Szilagyi L, et al. Regional distribution of human trypsinogen 4 in human brain at mRNA and protein level. Neurochem Res. 2007;32:1423-33.

47. Fridolf T, Sundler F, Ahren B. Pituitary adenylate cyclase-activating polypeptide (PACAP): occurrence in rodent pancreas and effects on insulin and glucagon secretion in the mouse. Cell Tissue Res. 1992;269:275-9.

48. Filipsson K, Pacini G, Scheurink AJ, Ahren B. PACAP stimulates insulin secretion but inhibits insulin sensitivity in mice. Am J Phys. 1998;274: E834-42.

49. Edwards AV, Bloom SR, Ghatei MA. Pancreatic endocrine responses to the peptides VIP and PACAP in the conscious calf. Exp Physiol. 1997;82:717-27.

50. Filipsson K, Tornoe K, Holst J, Ahren B. Pituitary adenylate cyclase-activating polypeptide stimulates insulin and glucagon secretion in humans. J Clin Endocrinol Metab. 1997;82:3093-8.

51. Murase T, Kondo K, Otake K, Oiso Y. Pituitary adenylate cyclase-activating polypeptide stimulates arginine vasopressin release in conscious rats. Neuroendocrinology. 1993;57:1092-6.

52. Seki Y, Suzuki Y, Baskaya MK, Saito K, Takayasu M, Shibuya M, et al. Central cardiovascular effects induced by intracisternal PACAP in dogs. Am J Phys. 1995;269:H135-9.

53. Lutz-Bucher B, Monnier D, Koch B. Evidence for the presence of receptors for pituitary adenylate cyclase-activating polypeptide in the neurohypophysis that are positively coupled to cyclic AMP formation and neurohypophyseal hormone secretion. Neuroendocrinology. 1996;64: 153-61

54. Anderson ST, Sawangjaroen K, Curlewis JD. Pituitary adenylate cyclaseactivating polypeptide acts within the medial basal hypothalamus to inhibit prolactin and luteinizing hormone secretion. Endocrinology. 1996;137:3424-9.

55. Ollmann MM, Wilson BD, Yang YK, Kerns JA, Chen Y, Gantz I, et al. Antagonism of central melanocortin receptors in vitro and in vivo by agouti-related protein. Science. 1997;278:135-8.

56. Shutter JR, Graham M, Kinsey AC, Scully S, Luthy R, Stark KL. 1997. Hypothalamic expression of ART, a novel gene related to agouti, is upregulated in obese and diabetic mutant mice. Genes Dev. 1997;11:593-602.

57. Lu D, Willard D, Patel IR, Kadwell S, Overton L, Kost T, et al. Agouti protein is an antagonist of the melanocyte-stimulating-hormone receptor. Nature. 1994;371:799-802.

58. Fan W, Boston BA, Kesterson RA, Hruby VJ, Cone RD. Role of melanocortinergic neurons in feeding and the agouti obesity syndrome. Nature. 1997:385:165-8.

59. McMinn JE, Wilkinson CW, Havel PJ, Woods SC, Schwartz MW. Effect of intracerebroventricular alpha-MSH on food intake, adiposity, c-Fos induction, and neuropeptide expression. Am J Physiol Regul Integr Comp Physiol. 2000;279:R695-703.

60. Hahn TM, Breininger JF, Baskin DG, Schwartz MW. Coexpression of Agrp and NPY in fasting-activated hypothalamic neurons. Nat Neurosci. 1998;1:271-2.

61. Broberger C, Johansen J, Johansson C, Schalling M, Hokfelt T. The neuropeptide Y/agouti gene-related protein (AGRP) brain circuitry in normal, anorectic, and monosodium glutamate-treated mice. Proc Nat Acad Sci USA. 1998;95:15043-8.

62. Clark JT, Kalra PS, Crowley WR, Kalra SP. Neuropeptide Y and human pancreatic polypeptide stimulate feeding behavior in rats. Endocrinology. 1984:115:427-9.

63. Catzeflis C, Pierroz DD, Rohner-Jeanrenaud F, Rivier JE, Sizonenko PC, Aubert ML. Neuropeptide $Y$ administered chronically into the lateral ventricle profoundly inhibits both the gonadotropic and the somatotropic axis in intact adult female rats. Endocrinology. 1993;132:224-34.

64. Crowley WR, Kalra SP. Neuropeptide Y stimulates the release of luteinizing hormone-releasing hormone from medial basal hypothalamus in vitro: modulation by ovarian hormones. Neuroendocrinology. 1987;46:97-103.
65. Kalra SP, Kalra PS, Sahu A, Crowley WR. Gonadal steroids and neurosecretion: facilitatory influence on LHRH and neuropeptide Y. J Steroid Biochem. 1987;27:677-82.

66. Malven PV, Haglof SA, Degroot H. Effects of intracerebral administration of neuropeptide-Y on secretion of luteinizing hormone in ovariectomized sheep. Brain Res Bull. 1992;28:871-5.

67. Kalra SP, Kalra PS. Nutritional infertility: the role of the interconnected hypothalamic neuropeptide Y-galanin-opioid network. Front Neuroendocrinol. 1996;17:371-401.

68. Kalra SP, Crowley WR. Norepinephrine-like effects of neuropeptide $Y$ on LH release in the rat. Life Sci. 1984;35:1173-6.

69. Kaynard AH, Pau KY, Hess DL, Spies HG. Third-ventricular infusion of neuropeptide $Y$ suppresses luteinizing hormone secretion in ovariectomized rhesus macaques. Endocrinology. 1990;127:2437-44.

70. Kaynard AH, Spies HG. Immunoneutralization of neuropeptide $Y$ suppresses luteinizing hormone secretion in rabbits. Endocrinology. 1991;128:2769-75.

71. McShane TM, May T, Miner JL, Keisler DH. Central actions of Neuropeptide-Y may provide a Neuromodulatory link between nutrition and reproduction. Biol Reprod. 1992:46:1151-7.

72. Matthews D. Investigating variation in reproductive responses to diet restriction in heifers. PhD thesis. Dublin: National University of Ireland, University College Dublin; 2011.

73. Ober JA, Malven PV. Effect of growth-retardation on pituitary luteinizinghormone and hypothalamic Neuropeptide-Y in Ovariectomized sheep. Neuroendocrinology. 1992;56:331-9.

74. McShane TM, Petersen SL, McCrone S, Keisler DH. Influence of food restriction on neuropeptide-Y, proopiomelanocortin, and luteinizing hormone-releasing hormone gene expression in sheep hypothalami. Biol Reprod. 1993:49:831-9.

75. Sahu A, Kalra PS, Kalra SP. Food deprivation and ingestion induce reciprocal changes in neuropeptide $Y$ concentrations in the paraventricular nucleus. Peptides. 1988;9:83-6.

76. Sahu A, Dube MG, Phelps CP, Sninsky CA, Kalra PS, Kalra SP. Insulin and insulin-like growth factor II suppress neuropeptide $Y$ release from the nerve terminals in the paraventricular nucleus: a putative hypothalamic site for energy homeostasis. Endocrinology. 1995;136:5718-24.

77. Schwartz MW, Sipols AJ, Marks JL, Sanacora G, White JD, Scheurink A, et al. Inhibition of hypothalamic neuropeptide $Y$ gene expression by insulin. Endocrinology. 1992;130:3608-16.

78. Lee DK, Cheng R, Nguyen T, Fan T, Kariyawasam AP, Liu Y, et al: Characterization of apelin, the ligand for the APJ receptor. J Neurochem. 2000;74:34-41

79. Taheri S, Murphy K, Cohen M, Sujkovic E, Kennedy A, Dhillo W, et al. The effects of centrally administered apelin-13 on food intake, water intake and pituitary hormone release in rats. Biochem Biophys Res Commun. 2002;291: 1208-12.

80. De Mota N, Reaux-Le Goazigo A, El Messari S, Chartrel N, Roesch D, Dujardin $C$, et al. Apelin, a potent diuretic neuropeptide counteracting vasopressin actions through inhibition of vasopressin neuron activity and vasopressin release. Proc Nat Acad Sci USA. 2004;101:10464-9.

81. Sunter D, Hewson AK, Dickson SL. Intracerebroventricular injection of apelin-13 reduces food intake in the rat. Neurosci Lett. 2003;353:1-4.

82. O'Shea M, Hansen MJ, Tatemoto K, Morris MJ. Inhibitory effect of apelin-12 on nocturnal food intake in the rat. Nutrl Neurosci. 2003;6:163-7.

83. Kopin AS, Mathes WF, McBride EW, Nguyen M, Al-Haider W, Schmitz F, et al. The cholecystokinin-a receptor mediates inhibition of food intake yet is not essential for the maintenance of body weight. J Clin Invest. 1999;103: 383-91.

84. Fichter MM, Pirke KM, Holsboer F. Weight loss causes neuroendocrine disturbances: experimental study in healthy starving subjects. Psychiatry Res. 1986;17:61-72.

85. Smith MJ, Wise PM. Neurotensin gene expression increases during proestrus in the rostral medial preoptic nucleus: potential for direct communication with gonadotropin-releasing hormone neurons. Endocrinology. 2001;142: 3006-13.

86. Akema T, Praputpittaya C, Kimura F. Effects of preoptic microinjection of neurotensin on luteinizing hormone secretion in unanesthetized ovariectomized rats with or without estrogen priming. Neuroendocrinology. 1987:46:345-9

87. Ferris CF, Pan JX, Singer EA, Boyd ND, Carraway RE, Leeman SE. Stimulation of luteinizing hormone release after stereotaxic microinjection of 
neurotensin into the medial preoptic area of rats. Neuroendocrinology. 1984;38:145-51.

88. Alexander MJ, Mahoney PD, Ferris CF, Carraway RE, Leeman SE. Evidence that neurotensin participates in the central regulation of the preovulatory surge of luteinizing hormone in the rat. Endocrinology. 1989;124:783-8.

89. Dungan Lemko HM, Naderi R, Adjan V, Jennes LH, Navarro VM, Clifton DK, et al. Interactions between neurotensin and GnRH neurons in the positive feedback control of GnRH/LH secretion in the mouse. Am J Physiol Endocrinol Metab. 2010;298:E80-8.

90. Elsik CG, Tellam RL, Worley KC, Gibbs RA, Muzny DM, Weinstock GM, et al. The genome sequence of taurine cattle: a window to ruminant biology and evolution. Science. 2009;324:522-8.

91. Langmead B, Trapnell C, Pop M, Salzberg SL. Ultrafast and memory-efficient alignment of short DNA sequences to the human genome. Genome Biol. 2009;10:R25.

92. Flicek P, Amode MR, Barrell D, Beal K, Brent S, Chen Y, et al. Ensembl 2011. Nucleic Acids Res. 2011:39:D800-6.

93. Anders S, Huber W. Differential expression analysis for sequence count data. Genome Biol. 2010;11:R106.

94. Benjamini Y, Hochberg Y. Controlling the false discovery rate - a practical and powerful approach to multiple testing. J R Statist Soc B. 1995;57: 289-300.

95. Lynn DJ, Winsor GL, Chan C, Richard N, Laird MR, Barsky A, et al. InnateDB: facilitating systems-level analyses of the mammalian innate immune response. Mol Syst Biol. 2008:4:218.

96. Young MD, Wakefield MJ, Smyth GK, Oshlack A. Gene ontology analysis for RNA-seq: accounting for selection bias. Genome Biol. 2010;11:R14.

\section{Submit your next manuscript to BioMed Central and we will help you at every step:}

- We accept pre-submission inquiries

- Our selector tool helps you to find the most relevant journal

- We provide round the clock customer support

- Convenient online submission

- Thorough peer review

- Inclusion in PubMed and all major indexing services

- Maximum visibility for your research

Submit your manuscript at www.biomedcentral.com/submit
Biomed Central 